Jurnal DIALOGIKA Manajemen dan Administrasi

Homepage: https://ejournal.unma.ac.id/index.php/dialogika

Vol. 2, No. 1 Oktober 2020 halaman: $26 \sim 33$

E-ISSN: 2720-9865, P-ISSN: 2716-3563

DOI : https://doi.org/10.31949/dialogika.v2i1.2174

\title{
STRATEGI PENINGKATAN PENGELOLAAN ASET DESA DI KABUPATEN MAJALENGKA
}

\author{
${ }^{1}$ Bani Fadilah Ranandar, ${ }^{2}$ Otong Karyono \\ ${ }^{1}$ Mahasiswa Magister Ilmu Administrasi, Universitas Majalengka, Jawa Barat, Indonesia \\ ${ }^{2}$ Magister Ilmu Administrasi, Pascasarjana Universitas Majalengka, Jawa Barat, Indonesia \\ e-mail korespondensi: bara.alfaiza@gmail.com
}

Disubmit Agustus 2020 , Diterima September 2020 , Diterbitkan Oktober 2020

Submitted August 2020, Accepted September 2020, Published October 2020

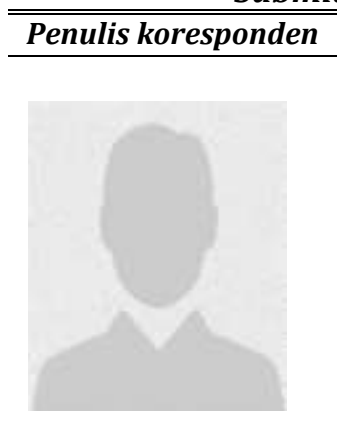

Jurnal DIALOGIKA

Manajemen dan

Abstract

Obstacles in reporting village assets because asset officers are less disciplined in collecting inventory data, so that the local government has not been able to conduct village asset appraisals. Supervision of the implementation of village asset management that should have been carried out by the Regional Government or the District Government has never been carried out. From the results of the analysis of the SWOT analysis strategy formulation strategy to increase village assets, it is found that the SWOT analysis quadrant is in quadrant II, namely the diversification strategy. This analysis has a number of strengths but there are several threats. The results of the analysis show that the current threat exists in the impact of the Covid 19 pandemic which has changed most of the development programs towards village assets in order to increase village income into social / assistance programs intended for highly affected communities. Even though the program comes from local, provincial and central governments, the involvement of assistance from the village itself is very strategic considering that assistance from local, provincial and central governments is relatively limited.

\section{Administrasi}

diterbitkan oleh

Program Studi

Administrasi Publik

Pascasarjana

Universitas

Majalengka
Keywords: Management, Village Assets, SWOT Analysis

\begin{abstract}
Abstrak
Terkendalanya Pelaporan aset desa dikarenakan petugas aset kurang disiplin dalam mengumpulkan data inventarisasi, sehingga Pemerintah Daerah belum bisa melakukan Penilaian aset desa. Pengawasan terhadap pelaksanaan pengelolaan aset desa yang seharusnya dilaksanakan oleh Pemerintah Daerah atau Pemerintah Kecamatan juga belum pernah dilakukan. Dari hasil analisis perumusan strategi analisis SWOT terhadap strategi peningkatan asset desa didapat bahwa kuadran analisis SWOT berada pada kuadran II yaitu strategi diversifikasi. Analisis ini memiliki sejumlah kekuatan namun terdapat beberapa ancaman. Hasil analisis menunjukkan ancaman yang ada saat ini terdapat pada dampak pandemic Covid 19 yang telah merubah sebagian besar program pembangunan-pembangunan terhadap asset desa dalam rangka meningkatkan pendapatan asli desa menjadi programprogram sosial / bantuan yang diperuntukkan terhadap masyarakat yang sangat terdampak. Meskipun program tersebut berasal dari pemerintah daerah, provinsi dan pusat, namun keterlibatan bantuan dari pihak desa sendiri sangatlah stratejik mengingat bantuan dari pemerintah daerah, provinsi dan pusat relative terbatas.
\end{abstract}

Kata kunci: Pengelolaan, Aset Desa, Analisis SWOT.

\section{PENDAHULUAN}

Pemerintah desa memiliki kekayaan untuk mendukung penyelengaraan pemerintahannya. Kekayaan atau Aset Desa merupakan salah satu hasil kekayaan dari desa yang harus dikelola dan dikembngkan keberadaannya. Pemerintah desa sebagai satu unsur dominan dari desa perlu 
memiliki pendapatan dan Aset Desa. Tanpa ditunjang oleh elemen-elemen ini pemerintah desa akan menemui kesulitan dalam menjalankan tugasnya. Namun kenyataannya penggelaan Aset Desa pada khususnya belum berjalan sebagaimana yang diharapkan, karena belum adanya pedoman pengelolaan yang memadai. Keberhasilan pengelolaan aset desa dipengaruhi oleh partisipasi masyarakat. Rizka (2013) menyatakan Kemiskinan yang merupakan masalah dan harus segera diselesaikan oleh pemerintah, terutama masalah kemiskinan yang ada di desa. Salah satu cara yang telah diupayakan oleh pemerintah untuk pengentasan kemiskinan terutama kemiskinan yang berada di desa adalah dengan melakukan pembangunan desa. Dalam pelaksanaan pembangunan desa haruslah ditunjang dengan pendapatan desa yang kuat. Maka dengan itu pengelolaan aset desa yang baik sangat diperlukan untuk pembangunan kesejahteraan desa.

Aset desa dapat berupa tanah kas desa, tanah ulayat, pasar desa, pasar hewan, tambatan perahu, bangunan desa, pelelangan ikan, pelelangan hasil pertanian, hutan milik desa, mata air milik desa, pemandian umum, dan aset lainnya milik desa (UU No. 6 Tahun 2014 Pasal 76 ayat 1). Ketika aset desa sudah diketahui, maka kebijakan pembangunan bisa terlaksana dengan baik karena mengacu pada aset yang dimiliki desa, sehingga peran kepala desa dalam pengelolaan aset desa dapat terlihat sebaliknya tanpa aset maka desa tidak mengetahui kekayaan yang dimiliki serta peran kepala desa dalam pengelolaan aset desa tidak terlihat.

Peraturan memberikan landasan bagi semakin otonomnya desa secara praktik, bukan hanya sekedar normative. Dengan adanya pemberian kewenangan pengelolaan asset desa (berdasarkan Permendagri Nomor 1 Tahun 2016) dan adanya (UndangUndang Nomor 6 Tahun 2014 tentang Desa), seharusnya desa semakin terbuka (transparan) dan responsible terhadap proses pengelolaan asset desa adalah keseluruhan kegiatan yang meliputi : perencanaan, penganggaran, penatausahaan, pelaporan, pertanggungjawaban dan pengawasan keuangan desa, sehingga hak otonomi tersebut diharapkan desa dapat mengelola keuangannya secara mandiri dalam mengelola dan mengunaan asset desa.

Pengelolaan aset desa dilaksanakan berdasarkan asas fungsional, kepastian hukum, transparansi, dan keterbukaan, efisiensi, akuntabilitas, dan kepastian nilai (Permendagri Nomor 1 Tahun 2016 Pasal 3). Pengelolaan keuangan dan aset desa menuntut kemampuan untuk selalu beradaptasi dengan tuntutan lingkungan yang selalu berubah. Kondisi lingkungan yang strategis adalah yang mau dan berusaha untuk menjawab tantangan zaman, (keterbatasan sumber daya masyarakat yang semakin tumbuh dan berkembang untuk dimanfaat, keterbukaan/ transparansi pengelolaan keuangan dan aset, akuntabilitas dalam laporan keuangan yang disajikan). Salah satu wujud yang memberikan pengaruh berarti pada suatu entitas adalah bentuk-bentuk kepedulian terhadap lingkungan di sekitarnya (Siti, 2015).

Kepala desa sebagai pemegang kekuasaan pengelolaan aset desa berwenang dan bertanggungjawab atas pengelolaan aset desa. Kepala desa sebagai pemegang kekuasaan pengelolaan aset desa mempunyai wewenang dan tanggungjawab menetapkan kebijakan pengelolaan aset desa, menetapkan pembantu pengelola dan petugas/pengurus aset desa, menetapkan penggunaan, pemanfaatan atau pemindahtanganan aset desa, menetapkan kebijakan pengamanan aset desa, mengajukan usul pengadaan, pemindahtanganan dan penghapusan aset desa yang bersifat strategis melalui musyawarah desa, menyetujui usul pemindahtanganan, penghapusan aset desa sesuai batas kewenangan, dan menyetujui usul pemanfaatan aset desa selain tanah dan bangunan.

Mengingat pengelolaan asset desa sangatlah luas, maka dalam penelitian ini difokuskan pada proses perencanaan, pengadaan, penatausahaan, pelaporan dan pengawasan. Perencanaan adalah tahapan kegiatan secara sistematis untuk merumuskan berbagai rincian kebutuhan barang milik desa. Pengadaan adalah kegiatan untuk melakukan pemenuhan 
kebutuhan barang dalam rangka penyelenggaraan pemerintahan desa. Sedangkan Penatausahaan adalah rangkaian kegiatan yang di lakukan meliputi pembukuan, inventarisasi dan pelaporan aset desa sesuai dengan ketentuan yang berlaku. Selanjutnya pelaporan merupakan salah satu bentuk pengamanan aset desa secara administrasi dan yang terakhir adalah pengawasan. (Permendagri No 01 Tahun 2016).

Fenomena pengelolaan aset desa di Kabupaten Majalengka, masih kurangnya pemahaman pemerintah desa dan TPK terhadap proses pengadaan, kesemuanya tidak terlepas dari proses perencanaan yang matang, selain itu belum mematuhi peraturan perundang-undangan yang berlaku. Mengingat proses pengadaan sangat rawan, jangan sampai akibat dari ketidaktahuan dapat menjadi bumerang bagi para pihak yang terlibat dalam pengadaan. Hal ini menjadi ketertarikan bagi penulis untuk meneliti pengelolaan aset desa karena pengadaan barang/jasa kebutuhan desa menggunakan APBDes yang sumbernya dari dana desa maupun ADD dengan kata lain aset desa seiring sejalan dengan dana desa, tidak bisa dipisahkan.

$$
\text { Permasalahan lainnya dalam }
$$
pengelolaan asset desa yang didasarkan pada berita Radar Cirebon.com (3 Februari 2014) menyatakan bahwa hampir sebagian besar kabupaten di Provinsi Jawa Barat dalam pelaporan pengelolaan asset desa pada umumnya masih Wajar Dalam Pengecualian (WDP). Sesuai dengan Peraturan Daerah Kabupaten Majalengka Nomor 11 Tahun 2014 pada pasal 11 ayat (1) menyebutkan bahwa kekayaan desa terdiri dari tanah kas desa, pasar desa, badan usaha milik desa, lumbung desa, pemandian umum dan obyek wisata, bangunan milik desa dan lain-lain kekayaan milik desa.

Meskipun dasar hukumnya tentang pengelolaan asset desa baik dari pemerintah pusat sampai pemerintah daerah dalam mengatur pengelolaan asset desa, namun permasalahan yang dihadapi oleh sebagian besar desa yang ada di Kabupaten Majalengka belum maksimal dalam pengelolaannya. Padahal saat ini pemerintah desa memiliki aset yang tidak sedikit jumlahnya, baik yang materi maupun yang non materi. Tidak hanya itu, aset berupa infrastruktur juga banyak dimiliki masing-masing desa. Meski demikian, untuk beberapa aset, khususnya asset yang secara geografis berada di desa namun secara struktural masih menjadi bagian dari administrasi pemkab, juga perlu diatur pengelolaannya. Meskipun saat ini desa memiliki hak yang kuat dalam pengelolaan asset sebagaimana diatur dalam UndangUndang Nomor 6 Tahun 2014 tentang Desa, namun dengan adanya permendagri dan perda tersebut diharapkan dapat menguatkan dari segi yuridis formal, sehingga pemerintah desa nantinya juga akan mandiri.

Dengan adanya penjelasan di atas mengenai Pengengelolaan Aset Desa pada Kabupaten Majalengka dapat diketahui bahwa pengelolaan aset desa tersebut belum menerapkan secara maksimal terhadap Permendagri 1 Tahun 2016, dan Pengelolaan Aset Desa belum berjalan dengan baik. Tujuan penelitian ini untuk mendeskripsikan aset desa Panjalin kidul Kecamatan Sumberjaya Kabupaten Majalengka, untuk mendeskripsikan pengelolaan aset desa Panjalin kidul Kecamatan Sumberjaya Kabupaten Majalengka, untuk mendeskripsikan kendala pengelolaan aset desa Panjalin kidul Kecamatan Sumberjaya Kabupaten Majalengka, dan untuk mendeskripsikan solusi untuk mengatasi kendala pengelolaan aset desa Panjalin kidul Kecamatan Sumberjaya Kabupaten Majalengka.

Kerangka konsep merupakan gambaran atau bangunan utuh suatu penelitian dan merupakan perpaduan dari berbagai aspek yang dimulai dari permasalahan, aspekaspek terkait yang hendak diteliti hingga kemungkinan-kemungkinan lain yang ingin dihasilkan dari keseluruhan proses penelitian. Dengan latar belakang masalah, rumusan permasalahan dikaitkan dengan teori yang ada maka kerangka konseptual dalam penelitian ini adalah sebagai berikut. 


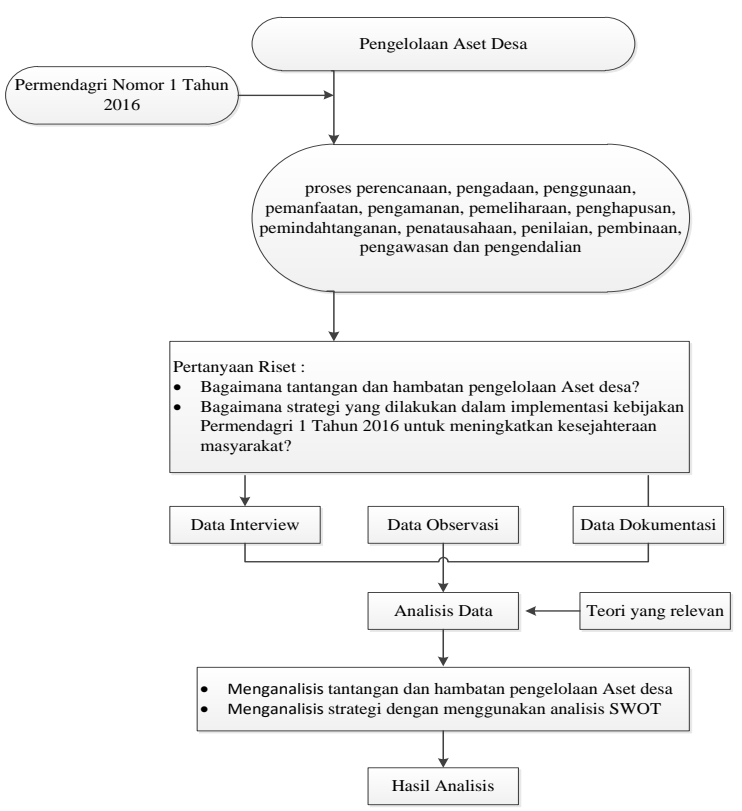

Gambar 1 Kerangka Konseptual

\section{METODE PENELITIAN}

Analisis SWOT merupakan teknik historis yang terkenal dimana para manajer menciptakan gambaran umum secara cepat mengenai situasi strategis organisasi (Pearce II \& Robinson, Jr, 2013:156). Menurut Griffin (dalam Sahroni, et.al., 2015) analisis SWOT adalah evaluasi atas kekuatan (strength) dan kelemahan (weaknesses) internal suatu organisasi yang dilakukan secara hat-hati, dan juga evaluasi atas peluang (opportunities) dan ancaman (threats) dari lingkungan. Proses penyusunan perencanaan strategis melalui tiga tahap analisis, yaitu (Rangkuti, 2015) :

1. Tahap pengumpulan data

Dalam tahap ini dilakukan pengumpulan data, pengklarifikasian, dan pra analisis. Data dibedakan menjadi dua jenis, yaitu data eksternal dan data internal. Model yang dipakai pada tahap ini yaitu matriks faktor strategi eksternal, matriks faktor strategi internal.

2. Tahap analisis

Setelah mengumpulkan semua informasi yang berpengaruh terhadap kelangsungan organisasi, tahap selanjutnya adalah memanfaatkan semua informasi tersebut dalam modelmodel kuantitatif perumusan strategi.

3. Tahap pengambilan keputusan

Setelah dilakukan analisis terhadap faktor-faktor eksternal dan internal akan diperoleh beberapa alternative strategi yang bisa digunakan oleh manajemen.

Analisis ini akan mengidentifikasi faktor-faktor internal (kekuatan dan kelemahan) dan faktor-faktor eksternal (peluang dan ancaman) yang mempengaruhi PAD, serta mencari strategi pemecahan dalam pengambilan keputusan dalam upaya peningkatan asset desa di Kecamatan Majalengka Kabupaten Majalengka.

Langkah pertama yang dilakukan dalam analisis SWOT adalah dengan mengidentifikasi faktor kekuatan dan kelemahan yang dimiliki, serta melihat peluang dan ancaman dalam kegiatan yang ada, kemudian dilakukan suatu perencanaan. Untuk pengukuran yang lebih akurat dilakukan teknik positing, yaitu menempatkan PAD dalam peta SWOT. Untuk melakukan positing diperlukan system pembobotan terhadap masingmasing aspek, dengan cara :

a. Terlebih dahulu membuat prosentase dari yang berpengaruh paling kuat ke paling lemah.

b. Menentukan prosentase bobor dari masing-masing aspek;

c. Menentukan skor masing-masing variabel (aspek yang berpengaruh);

d. Selanjutnya skor masing-masing dikalikan bobotnya;

e. Skor tertimbang dari masing-masing kelompok (eksternal dan internal) dijumlahkan untuk memperoleh skor total tertimbang.

f. Hasil perhitungan tersebut kemudian digunakan untuk menentukan letak aspek yang dianalisis pada peta/kuadran SWOT.

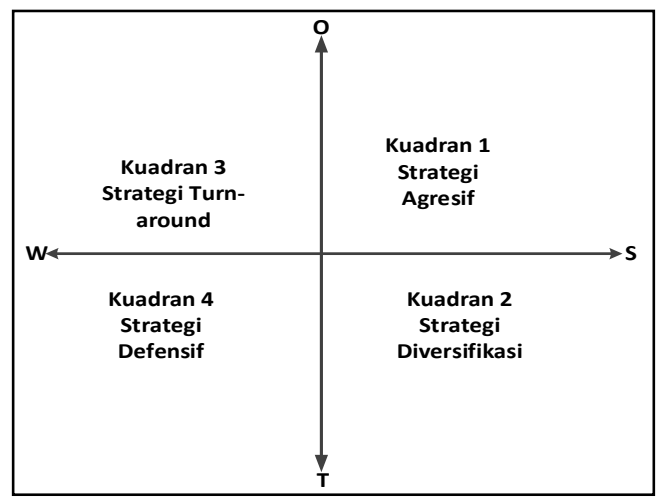

Gambar 2 Analisis Diagram SWOT 


\section{HASIL PENELITIAN DAN PEMBAHASAN}

\section{Analisis Tantangan dan Hambatan}

Secara umum, pengelolaan aset desa berlandaskan pada peraturan menteri dalam negeri nomor 1 tahun 2016. Namun dalam pengelolaan aset desa di Kecamatan Majalengka masih terdapat kendala. Hal tersebut dapat diketahui melalui pendapat yang dikemukakan oleh para narasumber. Sekretaris Desa Kawunggirang mengungkapkan permasalahan dalam mengelola aset desa, yaitu sebagai berikut:

"Pasti ada kesulitan yang didapatkan dalam pengelolaan aset desa, karena aturan itu berubah-ubah. Seandainya aturan tahun ini sama dengan aturan tahun depan, pasti kita sudah bisa menguasainya. Tapi terkadang aturan berubah-ubah, yang mengharuskan kita memperbanyak konsultasi ke Kecamatan atau Kabupaten". (Hasil wawancara dengan Sekdes Kawunggirang, tanggal 22 Agustus 2020).

Dari hasil wawancara diatas dapat disimpulkan bahwa aparatur desa masih memerlukan pendampingan dari aparat pemerintah daerah guna penyesuaian perubahan aturan setiap tahun. Permasalahan lain yang muncul dalam pengelolaan aset desa yaitu kurangnya Sumber Daya Manusia (SDM) yang siap untuk mengelola aset desa. Hal tersebut di ungkapkan pada hasil wawancara oleh Sekretaris Desa Ciboda, yaitu: "Dalam mengelola aset desa ada beberapa kesulitan yangdihadapi, termasuk kompetensi Sumber Daya Manusia (SDM) pengelola yang kurang maksimal kinerjanya dan terbatasnya SDM, sehingga saya juga ikut turun tangan dalam mengelola aset desa". (Hasil wawancara dengan Sekdes Balumbung, tanggal 25 Agustus 2020).

\section{Strategi Peningkatan Aset Desa}

Sebelum di akukan analasis SWOT, dilakukan klasifikasi dan analisis faktor internal (kekuatan dan kelemahan usaha). Prosedur analisis faktor-faktor internal (IFAS=Internal Factor Analysis Summary) adalah sebagai berikut:

1) Disusun faktor-faktor yang menjadi kekuatan dan kelemahan.
2) Dilakukan pemberian bobot dari 1,00 hingga 0,00 (dari sangat penting hingga tidak penting) tergantung besarnya dampak faktor tersebut.

3) Dilakukan pemberian rating skala 4-1 untuk kekuatan (kekuatan yang besar diberikan nilai 4 dan yang paling kecil diberikan nilai 1).

4) Dilakukan pemberian rating skala 1-4 untuk kelemahan (kelemahan yang besar di berikan nilai 1 dan yang paling kecil diberikan nilai 4).

5) Dilakukan perkalian antar bobot dengan rating sehingga diperoleh nilai untuk setiapa faktor.

6) Nilai setiap faktor di jumlahkan sehingga diperoleh nilai total untuk faktor strategi eksternal. Nilai ini menunjukkan bagaimana perusahaan bereaksi terhadap faktor-faktor internalnya dan dapat digunakan sebagai pembanding untuk perusahaan sejenis.

Setelah itu dilakukan klasifikasi dan analisis faktor-faktor strategi eksternal (EFAS=External Factor Analysis Sunmary). Prosedur analsis faktor-faktor adalah sebagai berikut (Rangkuti, 2002):

1. Disusun faktor-faktor yang menjadi peluang dan ancaman

2. Dilakuukan pemberian bobot dari 1,00 hingga 0,00 (dari sangat penting hingga tidak penting) bergantung besarnya dampak faktor tersebut.

3. Dilakukan pemberian rating skala 4-1 untuk peluang (pluang yang besar).

4. Dilakukan pemberian rating skala 1-4 untuk ancaman (ancaman yang besar).

5. Dilakaukan perkalian antar bobot dengan rating sehingga diperoleh nilai untuk setiap faktor.

Nilai setiap faktor di jumlahkan sehingga diperoleh nilai total untuk faktor strategi eksternal. Nilai ini menunjukkan bagaimana organsasi bereaksi terhadap faktor-faktor eksternalnya dan dapat digunakan untuk menganalisis faktor peluang dan ancaman terhadap organisasinya. adapun faktor analisis internal dan eksternal pada penelitian ini diuraikan sebagai berikut: 
1. Faktor internal

a. Kekuatan (strengths)

- Struktur kelembagaan

- Kondisi geografis wilayah

- Sumber daya alam

- Sarana dan prasarana

- Pengelolaan dana desa

b. Kelemahan (weaknesses)

- Kualitas SDM

- Keterbatasan SDM

- IPTEK

- Kebijakan yang dinamis

- Manajemen Aset

2. Faktor eksternal

a. Peluang (opportunities)

- Potensi Wisata

- Potensi pertanian

- regulasi

- potensi perkebunan

- potensi tenaga kerja

b. Ancaman (threats)

- Covid 19

- Kemiskinan

- Pengangguran

- Profesionalitas pengelolaan asset

- Penguasaan teknologi

Berdasarkan faktor internal dan eksternal tersebut, maka matriks IFAS (Internal factor Analysis Summary) dan EFAS (eksternal Factor Analysis Summary) dapat dilihat pada Tabel 1 dan 2.

Tabel 1 Faktor Internal (Strength dan Weaknesses)

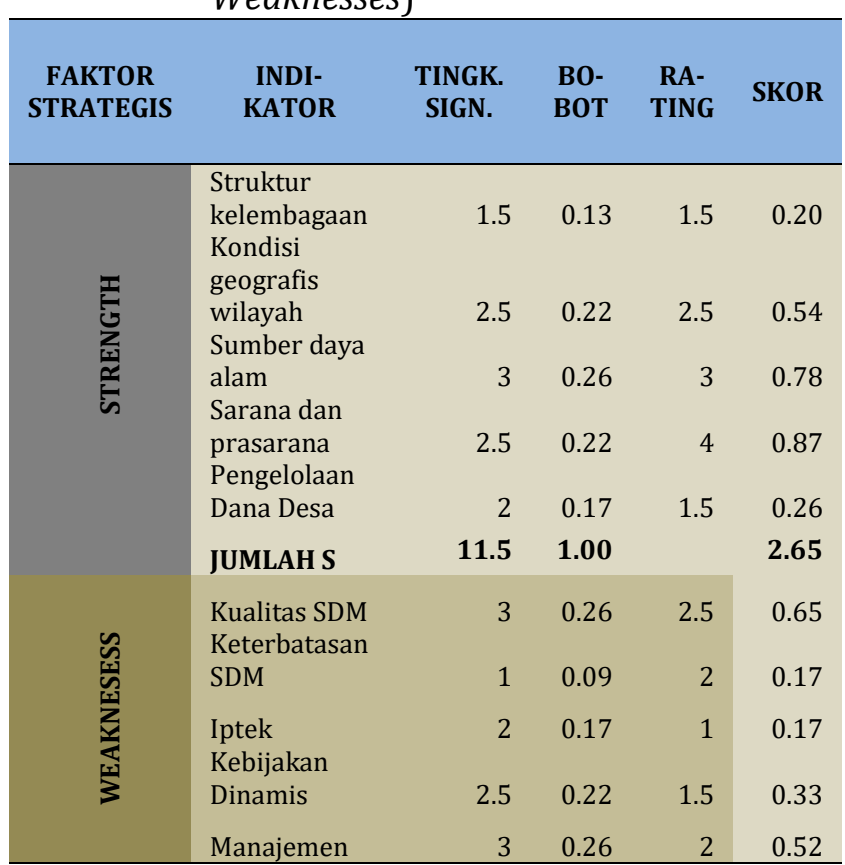

\begin{tabular}{llll}
\hline Aset & & & \\
JUMLAH W & 11.5 & 1.00 & 1.85 \\
Selisih & & & \\
\hline
\end{tabular}

Berdasarkan hasil matriks IFAS (Tabel 1) diperoleh nilai 0,85 dan matriks EFAS (Tabel 2) diperoleh nilai -0,25. Sedang untuk matriks SWOT Strategi peningkatan asset desa disajikan pada Tabel 2.

Tabel 2 Faktor Eksternal (Opportunity dan Threatment)

\begin{tabular}{|c|c|c|c|c|c|}
\hline $\begin{array}{c}\text { FAKTOR } \\
\text { STRATEGIS }\end{array}$ & $\begin{array}{l}\text { TINGK. } \\
\text { SIGN. }\end{array}$ & $\begin{array}{l}\text { TINGK. } \\
\text { SIGN. }\end{array}$ & $\begin{array}{l}\text { BO- } \\
\text { BOT }\end{array}$ & $\begin{array}{l}\text { RA- } \\
\text { TING }\end{array}$ & SKOR \\
\hline \multirow{6}{*}{ 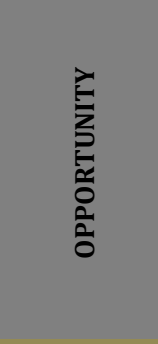 } & Potensi wisata & 3 & 0.22 & 3 & 0.67 \\
\hline & $\begin{array}{l}\text { Potensi } \\
\text { pertanian }\end{array}$ & 3 & 0.22 & 4 & 0.89 \\
\hline & Regulasi & 2.5 & 0.19 & 5 & 0.93 \\
\hline & $\begin{array}{l}\text { Potensi } \\
\text { perkebunan }\end{array}$ & 2 & 0.15 & 4.5 & 0.67 \\
\hline & kerja & 3 & 0.22 & 2 & 0.44 \\
\hline & JUMLAH 0 & 13.5 & 1.00 & & 3.59 \\
\hline \multirow{7}{*}{ 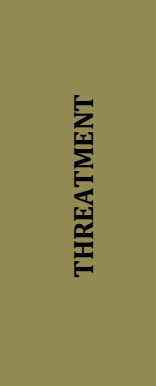 } & Covid 19 & 2 & 0.16 & 3.5 & 0.56 \\
\hline & Kemiskinan & 3 & 0.24 & 3 & 0.72 \\
\hline & Pengangguran & 3 & 0.24 & 4.5 & 1.08 \\
\hline & $\begin{array}{l}\text { Profesionalitas } \\
\text { dalam }\end{array}$ & & & & \\
\hline & asset desa & 2.5 & 0.20 & 5 & 1.00 \\
\hline & $\begin{array}{l}\text { Penguasaan } \\
\text { teknologi }\end{array}$ & 2 & 0.16 & 3 & 0.48 \\
\hline & JUMLAH T & 12.5 & 1.00 & & 3.84 \\
\hline
\end{tabular}

Berdasarkan hasil analisis dan perhitungan terhadap faktor internal dan eksternal diperoleh hasil analisis internal (kekuatan dan kelemahan) adalah 0,80 dan analisis eksternal (peluang dan ancaman) adalah 0,25 . Hasil analisis tersebut digunakan untuk menentukan posisi dalam kuadran SWOT, sebagai berikut : 


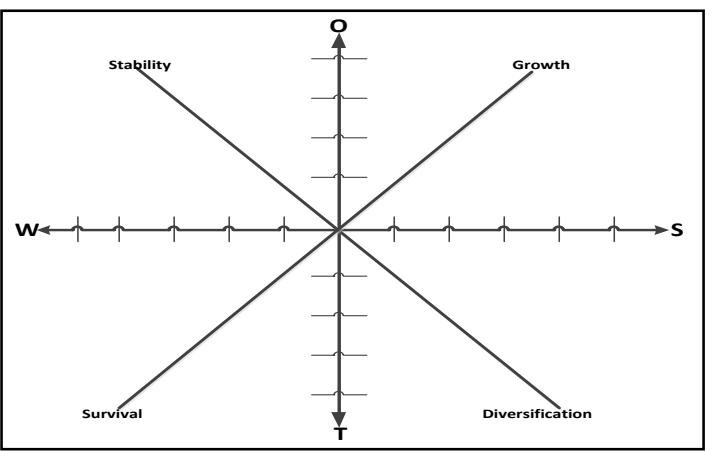

Gambar 3 Analisis Diagram SWOT Peningkatan Aset Desa di Kabupaten Majalengka

Dari gambar diagram SWOT di atas dapat dilihat bahwa posisi Kecamatan Majalengka berada pada kuadran 2, yaitu Kecamatan Majalengka menghadapi berbagai ancaman dalam upaya peningkatan kinerja Aset Desa terutama dalam ancaman Covid 19 ini yang telah banyak mengalihkan program-program pengembangan asset desa menjadi program-program sosial dalam rangka penguatan ekonomi masyarakat desa khususnya di Kecamatan Majalengka, namun di sisi memiliki kekuatan dari segi internal yaitu kepemilikan sumber daya alam dan beberapa potensi yang dimiliki oleh desa di kecamatan Majalengka. Fokus strategi yang harus dilakukan adalah menggunakan kekuatan untuk memanfaatkan peluang jangka panjang dengan cara strategi diversifikasi.

\section{PENUTUP}

Hasil penelitian telah membuktikan bahwa SWOT analisis telah mampu membuktikan secara empiris terhadap strategi yang perlu dilakukan dalam meningkatkan asset desa di Kabupaten Majalengka, yaitu dengan meningkatkan kekuatan untuk memperkecil ancaman. Penelitian ini mendukung terhadap hasil penelitian yang dilakukan oleh Karyono dan Agustina (2019) bahwa dalam penelitian mengungkapkan bahwa SWOT analisis mampu memetakan strategi dalam implementasi e-government pada pemerintahan.

\section{DAFTAR PUSTAKA}

Anggraeni, D.M \& Saryono. 2013. Metodelogi Penelitian Kualitatif dan.
Kuantitatif dalam Bidang Kesehatan. Yogyakarta: Nuha Medika.

Eko, Sutoro et al. 2014Desa Membangun Indonesia. Yogyakarta: Forum Pengembangan. Pembaharuan Desa (FPPD).

Karyono, Otong dan Kania Agustina. 2019. Determining the Priority Strategy in the Implementation of E-Government Through Swot Analysis Model. Budapest International Research and Critics Institute-Journal (BIRCIJournal) Volume 2, No 2, May 2019, Page:66-74 e-ISSN: 26153076(Online), p-ISSN: 26151715(Print).

Keban, T. Yeremias. 2004. Enam Dimensi Strategis Administrasi Publik, Konsep,. Teori dan Isu. Gava Media. Yogyakarta.

Moleong, Lexy J. (2007) Metodologi Penelitian Kualitatif, Penerbit PT Remaja Rosdakarya.

Pasolong, Harbani. 2011. Teori Administrasi Publik. Bandung: Alfabeta.

Peraturan Menteri Dalam Negeri Nomor 1 Tahun 2016 Tentang Pengelolaan Aset Desa.

Pratama, M. Hamdani. 2015. Strategi Meningkatkan Kualitas Pelayanan Publik. Surabaya: Universitas Airlangga.

Sutaryono, dkk. 2014. Pengelolaan Aset Desa. Forum Pengembangan Pembaharuan Desa (FPPD): Sleman Yogyakarta.

Undang-Undang Nomor 6 Tahun 2014 Tentang Desa, Lembaran Negara Republik Indonesia Tahun 2014 Nomor 7, Tambahan Lembaran Negara Nomor 5495.

Wijayanti, Efi. 2015. Eksistensi Pemerintah Desa Dalam Pengelolaan Sumber Air Bendorogo Di Desa Bekiring Kecamatan Pulung Kabupaten Ponorogo. Skripsi. Universitas Muhammadiyah Ponorogo. 


\section{BIOGRAFI PENULIS}

\begin{tabular}{||l|l||}
\hline & Bani Fadilah Ranandar, Mahasiswa Program Magister Ilmu Administrasi, \\
& Universitas Majalengka, Jawa Barat, Indonesia. \\
& e-mail: bara.alfaiza@gmail.com \\
& \\
\hline \hline & $\begin{array}{l}\text { Otong Karyono, Lektor, Kaprodi Magister Ilmu Administrasi, Manajemen Strategik } \\
\text { dan Metodologi Penelitian. } \\
\text { Email: karyono.otong@gmail.com }\end{array}$ \\
\hline
\end{tabular}

